\title{
An analysis of the application of pleasurable teaching methodology in track
}

\author{
and field teaching \\ Lin Zhai \\ Physical Education School of Shaanxi Normal University, \\ Xi'an, Shaanxi, 710119
}

\begin{abstract}
The deepening of educational reform and the issuing of the new curriculum reform lead to that traditional track and field teaching cannot satisfy the needs of contemporary education. In accordance with the demand of education for all-round development and the new curriculum reform for pleasurable track and field teaching, pleasurable teaching is developed and introduced rapidly. Pleasurable track and field teaching brings new energy and driving force of development to physical education and is well received among students and teachers. Compared with traditional teaching, pleasurable teaching changes the way of teaching greatly; it not only improves students' physical fitness and adds training modes but also stimulates students' interest in learning and make them participate in teaching positively, thus enhancing teaching efficiency. Then the article will analyze the feasibility of pleasurable track and field teaching and elaborate the specific applications of pleasurable teaching in track and field teaching.
\end{abstract}

Key words-Pleasurable teaching
methodology, Track and field teaching,
Applications

\section{INTRODUCTION}

Education reform puts forward higher requirements for track and field teaching. However, traditional teaching methods emphasizes the results of training excessively and students can improve their track and field skills only through dull, tedious and repeated training. Such kind of teaching method is easy to arouse students' aversion and they will try to deal with training negatively, thus losing the original purpose of the training. The introduction of pleasurable track and field teaching enriches the content of track and field teaching; it improves students' sports ability and physical fitness whilst stimulates students' learning interest, and thus enhances the efficiency of track and field teaching. Therefore the teaching objectives can be completed effectively.

II Feasibility of the application of pleasurable teaching in track and field teaching

(I) Pleasurable track and field teaching has looser demands for the hardware environment. Pleasurable teaching does not need special sites or professional teaching instruments and it can be conducted on the playground of a school [1]. Even if the playground of some schools is not 
qualified, teachers can lead students to an open place or a piece of lawn to present pleasurable track and field teaching. In addition, the sport equipment used during pleasurable track and field teaching is relatively simple, without rigorous technical requirements or fund requests, so a school can satisfy the demand of track and field courses for equipment. The use of those devices also will arouse students' interest in track and field learning and enhance students' enthusiasm in learning, thus laying a good foundation for cultivating students' lifelong sport consciousness.

(II) Pleasurable physical education is well received among university teachers.

Track and field teachers are both the organizers and performers of teaching. Therefore teachers are most qualified to say whether a teaching method is reasonable or not. A survey on track and field teachers demonstrates that the proportion of the teachers who accept traditional teaching more is $20 \%$ while the those who accept pleasurable track and field teaching account for $80 \%$. So it can be seen that pleasurable track and field teaching is highly recognized by physical education teachers. Meanwhile teachers' recognition of a teaching method directly affects the performance and effects of teaching [2].

(III) Relieve students' learning stress

The basis that pleasurable track and field teaching can relieve students' stress is that pleasurable teaching is able to bring students pleasure, so students will participate in teaching activities and finish track and field training with a relaxed and pleasant mood, and pleasurable teaching also adds students' pleasant sensation and joy of life, improves ponderous learning atmosphere and allow students to experience the happiness of sports, and teachers can set some training objectives when students are doing sports, which will strengthen students' sense of pride and sense of achievement after they accomplish those objectives and satisfy their psychological needs.

(IV) Pleasurable track and field teaching

Due to it has great pleasure and is easy to arouse students' learning interest and enhance teaching efficiency, pleasurable track and field teaching is widely recognized by physical education teachers and students. And pleasurable track and field teaching has lower requirements on the site and equipment, so most schools can provide corresponding hardware support; besides, the time of pleasurable track and field teaching is random, and thus it is appropriate for students to have training during their spare time [3].

\section{Specific applications of pleasurable teaching in track and field teaching}

(I) Integrate interesting stories into track and field teaching

It seems that stories have nothing to do with track and field teaching on the surface, and it is hard to connect such kind of teaching method with traditional teaching, but pleasurable teaching does connect the two things together although they have nothing to do with each other or even run in the opposite direction. The introduction of interesting stories can stimulates students' learning interest and the combination of both can achieve unexpected results.

For example, when teachers are teaching students the knowledge on long jump, before the official start of the training, they can tell students some interesting stories which can be fables, fairy tales or some things actually happening around them. Take the author as an example. When I once took a physical education exam, a student in the same team with mine liked to judge others particularly. When other 
students were jumping, he/she would say, "you look like a frog when jumping and it is really ugly" or "if I jump such a distance, I will be embarrassed to take the exam" or "is long jump really so hard? I look down upon you as you cannot jump over such a short distance". In a word after each student in front of him/her finished the jump, he would offer a comment and it was a negative comment. At last it was his turn. All the classmates had thought that his/her action must be quite qualified. However, the result was out of everyone's expectation. Not only was his/her action below the standard, but also his/her performance was not qualified. At last the student lowered his/her head and no longer judged other students at his/her own will. Use this sort of digressions to guide students to standardize their actions in long jump and then lead students to have training [4].

It is not hard to combine pleasurable teaching method, but teachers must prepare some storied related to the course being taught before giving a lesson. So teachers shall pay attention to collecting stories in their daily life and in this way pleasurable track and field teaching will yield good results.

(II) Integrate interesting games into track and field teaching

In traditional track and field teaching, teachers' teaching methods are old-fashioned and unitary. They generally adopt the teaching method which has three steps: teachers' demonstration, teaching and students' training. Such kind of teaching method will arouse students' aversion and thus reduce teaching efficiency. Regarding this question physical education teachers must reform and innovate the method of track and field teaching accordingly and develop some teaching methods suitable for students' physical and mental development to raise students' enthusiasm in learning.

So teachers shall have an open mind toward track and field teaching and shall not be restricted by traditional teaching methods, be bold to innovate and design some games related to the content of courses to assist their teaching. And this kind of teaching method will be easily accepted by students and does great help to improve students' sports ability, arouse students' interest in track and field and cultivate students' lifelong sport consciousness [5].

(III) Use teaching props to add the pleasure brought about by track and field teaching

To improve the effectiveness and pleasure of track and field teaching, teachers can make some props to assist their teaching. Students also can take part in the making of those props and students' learning interest can be aroused in this way.

For example, during long-distance running training, teachers can make some small colored flags together with students and then plant those flags on the playground. A student will win a flag for each round he/she finishes. The students who wins the most flags will be the winner. Such kind of method not only exaggerates the atmosphere of long-distance running but also stimulates students' competitiveness effectively. A positive competition mechanism will come into being during the long-distance running process and thus all students' running ability can be improved. Carry out this kind of training frequently and each student will try hard to do running exercises. During the process, students will not feel tired and their physical skills can be enhanced. Take another example. Teachers can let students use their imagination and decorate the hurdles according to their own preference. Students will be more excited about the hurdles they design by themselves and will take an 
active part in the hurdling training. The teaching mode is fresh and unique. With students as the teaching subject, students' individuality can be displayed fully. So it will be well received by students whilst enhance teaching efficiency.

Using self-made teaching aids to add pleasure to track and field teaching achieves good results according to the author's years of practical application. So hope teachers can constantly improve and develop the teaching method and thus add pleasure to track and field teaching.

(IV) Introduce multimedia teaching into track and field teaching

It can be found that students are more interested in multimedia teaching based on the observation of other teaching modes. So appropriate introduction of multimedia teaching is able during physical education. But the common site for track and field teaching is outdoor field, which hinders multimedia teaching. For this problem, the author designs the following scheme:

Still take hurdling training as an example. Students are hard to master standard actions of hurdling. Although the teacher demonstrates those actions many times, the result is not good. The reasons are: firstly, the actions of hurdling are hard to be mastered. Though students try their best to imitate the teacher's actions, they cannot find their mistakes during practice; secondly, students are not serious about the training and do not try their best. Based on the two kinds of mentality, the author records each student's actions with a camera and then display the video in front of students via multimedia. Those students who do not get the essentials will suddenly be enlightened after watching the video and those who do not try their best will find their actions are so funny, and henceforth they will take the training seriously.

Using multimedia to demonstrate students' unqualified actions is not a kind of punishment or slight; the aim is to make students know their deficiencies clearly. Meanwhile the display of those funny actions can activate classroom atmosphere and adds pleasure to the course. All students' actions will be displayed, so they will not have the inferiority complex. At last with the comparison of two successive hurdling training, students will know the teacher's purpose and henceforth they will finish the training of standard actions better.

\section{Conclusion:}

In conclusion, after educational reform, it emphasizes the cultivation of students' interest more during teaching. So teachers must actively improve their ways of teaching and introduce pleasure into classrooms, and thus stimulate students' learning interest and enhance teaching efficiency. The thesis analyzes the feasibility of pleasurable teaching based on the understanding of pleasurable teaching and the combination of pleasurable teaching and track and field teaching. And the author simply discusses the specific applications of pleasurable teaching in combination of his/her own experience in teaching. He/she applies interesting stories, games, self-made props and multimedia to track and field teaching and uses a new way to conduct track and field teaching. In this way the teaching is more interesting; students' enthusiasm is aroused and the teaching efficiency is elevated.

\section{Reference}

[1] Bangrong Peng, An effective exploration of adding pleasure to the track and field teaching in universities [J], Contemporary Sports Technology, vol. 16, pp. 145-145, 147, 2014. 
[2] Bingnan Han, An effective analysis of the pleasure of track and field teaching in universities [J], Sports, vol. 6, pp. 81-82, 2016.

[3] Kequan Zhang, Zhijian Chen, On the way of adding pleasure to track and field teaching $[\mathrm{J}]$, Journal of Longdong University, vol. 1, pp. 134-137, 2015.

[4] Yuanmu Huang, How to add pleasure to track and field teaching in universities [J], Journal of Heilongjiang Vocational Institute of Ecological Engineering, vol. 26(60, pp. 137-138, 2013.

[5] Caixia Yang, A study of the application and role of pleasurable physical education programs in track and field teaching [J], Sports Forum, vol. 9, pp. 73-75, 2014. 